\title{
GO GREEN
}

\author{
ANDI IRMAWATI PRATAMI \\ 9173770410149 \\ irmapratami01@gmail.com
}

1. Bentuk Kegiatan

$>$ Menanam Pohon.

2. Lokasi

$>$ Lapangan Olahraga Desa Bontocini.

3. Hari/Tanggal dan Waktu

> Sabtu, 07 November 2020 pukul 15:00 - 16:35.

4. Peserta Yang Dilibatkan

> Mahasiswa KKLP Yapti Jeneponto.

5. Alasan Diadakannya

> Alasan diadakannya Go Green karena melihat keadaan lapangan Bontocini tidak ada pepohonan hijau yang dapat membuat lapangan menjadi rindang.

6. Tujuan dan Manfaat

$>$ Tujuan dan Manfaat dari penghijauan ini adalah untuk menyadarkan kita agar menjaga dan melestarikan alam, dengan adanya pepohonan dapat menyerap air sehingga menghindari terjadinya banjir.

7. Deskripsi Kegiatan

> Kegiatan ini dilakukan di lapangan olahraga desa Bontocini, kami menanam pohon di pinggiran lapangan sebanyak 6 pohon. Go green dilakukan pada sore hari, dengan langkah pertama dilakukan penggalian tanah sebagai media tanam pohon, selanjutnya pohon ditanam serta di timbun, kemudian di lakukan penyiraman agar tanaman terhidrasi sampai esok hari. 